\title{
Antitumor effect and apoptosis induction of Alocasia cucullata (Lour.) G. Don in human gastric cancer cells in vitro and in vivo
}

Peng Wei ${ }^{1,2+}$, Chen Zhiyu ${ }^{1,2+}$, Tang $\mathrm{Xu}^{3}$ and Zheng Xiangwei ${ }^{4^{*}}$

\begin{abstract}
Background: Alocasia cucullata (Lour.) G. Don was applied in traditional Chinese medicine for the treatment of cancer in Chinese Southwest area. Its antitumor effect was scrutinized in vitro and in vivo. And for the first time, the mechanism of extract of A. cucullata (EAC) against human gastric cancer cell was well examined.

Methods: To detect the most effective fraction, the antiproliferation efficacy of four fractions (namely derivatives by adding $\mathrm{EAC}$ to $\mathrm{n}-\mathrm{BuOH}$, petroleum ether, EtOAc and water until dissolve fully) against five cancer cell lines were screened by MTT assay. Among four fractions, the IC50s of n-BuOH fraction of EAC (EAC-B) against the five cell lines and time-dependent inhibition to gastric cancer cell line (MGC-803) were further investigated (MTT assay). In vivo antitumor efficacy of EAC-B was examined by MGC-803 bearing tumor nude mice. Especially, the paper focused on the relevant mechanism study of EAC-B against MGC-803 included cell cycle distribution (flow cytometry) and cyclin D1 expression (RT-PCR and western blot), apoptosis (Hoechst 33342 stain and flow cytometry), apoptosis-related protein expression (Akt, p-Akt, ERK, p-ERK, Bcl-2, Bax) by western blot, and caspase3/7 activity assay.
\end{abstract}

Results: EAC-B showed its cytotoxicity against various tumor cell lines, particularly against gastric cancer cells with IC50 value of $18.8 \mu \mathrm{g} / \mathrm{mL}$ in vitro. Tumor weight was significantly reduced by EAC-B in vivo. In the mechanism study, EAC-B increased cell ratio at G0/G1 phase and reduced cyclin D1 expression both at protein and mRNA level on MGC-803. Chromatin condensation and apoptosis were also observed. EAC-B down-regulated p-Akt, p-ERK expression and up-regulated $\mathrm{Bax} / \mathrm{BCl}-2$ ratio. Further, caspase 3/7 activation was enhanced as well.

Conclusions: This study demonstrated that EAC-B had potent antitumor activity both in vitro and in vivo. Its mechanism is primarily via antiproliferation of GO/G1 arrest and cell pro-apoptosis, including Pl-3 K/Akt pathway, ERK activity, stimulated cytochrome $C$ release and caspase $3 / 7$ activity accompanied with an increase of Bax/Bcl-2 ratio. EAC-B may be a potential source of novel compounds for gastric cancer treatment.

Keywords: Alocasia cucullata, Gastric cancer, Cell cycle arrest, Apoptosis, In vivo

\section{Background}

Cancer as a world-wide concern remains major threat to people health despite advances in modern medical diagnosis and treatment [1]. Gastric cancer (GC) is the fourth most common malignancy and the second most dangerous cause of cancer mortality. According to statistics in the magazine as GLOBOCAN 2008 [2], 989,600 new GC cases

\footnotetext{
* Correspondence: zhengxwsh@hotmail.com

${ }^{\dagger}$ Equal contributors

${ }^{4}$ Shanghai University of Traditional Chinese Medicine Engineering Research Center of Modern Preparation Technology of TCM, Ministry of Education, Room1107, No. 1200 Cai Lun Road, Pudong District, Shanghai, China

Full list of author information is available at the end of the article
}

were recorded and 738,000 deaths occurred. GC is usually treated with adjuvant chemotherapy prior to and after surgery to prevent cancer recurrence. A meta-analysis demonstrated that 5 -year overall survival increased by $6 \%$ with chemotherapy compared to surgical treatment alone [3]. A significant and continuous need for effective anticancer agents was called for. Fortunately, Paclitaxel (Taxol) is proved to be a successful drug extracted from natural product to answer the call to fill the need. The significance of healing property herbs has been highly evaluated in drug discovery. However, only $15 \%$ and $6 \%$ of these plants have 
been screened for phytochemical analysis and bioactivity, respectively [4].

Accumulated studies have shown that Chinese traditional herbs may reduce the side effects, prolong survival time and improve the quality of life [5]. A review showed that GC was top 3 of the reported cancers treated with traditional Chinese medicine in China [6]. For instance, "Huachansu" has shown significant effects on the improvement of leukopenia, adverse events and rate of short-term remission in the advanced or late GC patients [7].

Alocasia cucullata (Lour.) G. Don (Chinese taro) (AC) in the Araceae family is a fast growing and propagating herbaceous species prevalent in South China [8]. Its tuber (Chinese name "jianweiyu") is a well-known ethnic medicine of the Zhuang nationality in China and is usually applied to reduce swelling, to detoxify and to ease pain $[9,10]$. For centuries in China, the interesting thing is that it has also been playing role in treatment of cancer in clinical application, including GC [11-13]. Pharmacological studies showed that an $\mathrm{N}$-acetyl-D-lactosamine lectin from $\mathrm{AC}$ had the antiproliferation effect against human $\mathrm{SiHa}$ cancer cells [14], and our previous studies also proved that the $50 \%$ ethanol extract of $A$. cucullata (EAC) was found to have the most potent antiproliferation effect on five cancer cells among 50\% ethanol, 95\% ethanol and water extracts. EAC petroleum ether extractive fraction (EAC-PE) also showed weak antiproliferation effect on MGC-803 and 43 ingredients in this fraction were identified through GC-MS [15]. Above studies proved the antitumor activity of $\mathrm{AC}$ and initiated the pharmacological research of AC.

In the antitumor mechanism study, $\mathrm{AC}$ was reported to be effective on breast cancer [16] while A macrorrhiza was reported on the hepatic cancer [17]. It was the first time for GC that the antitumor effect of EAC in vitro and in vivo were further evaluated and the possible mechanisms was elucidated by us.

In the study, the antiproliferation effect of four EAC fractions including $\mathrm{n}-\mathrm{BuOH}$ fraction against five cancer cell lines was screened. HPLC demonstrated the phytochemistry difference between $\mathrm{n}-\mathrm{BuOH}$ and petroleum ether fractions. Further, the inhibition to tumor growth in vivo was evaluated with the $\mathrm{n}-\mathrm{BuOH}$ fraction of EAC (EAC-B). We also investigated the mechanisms why EAC$B$ inhibited the cell proliferation including apoptosis and cell cycle arrest.

\section{Methods}

\section{Plant material}

The tubers of $A C$ were collected in Sichuan Province, China in spring, and were authenticated by Professor Baokang Huang (the School of Pharmacy, Second Military Medical University, Shanghai, China). A voucher specimen (Zheng 5470) has been deposited in the Department of Chinese
Materia Medica, Shanghai University of Traditional Chinese Medicine.

\section{Extraction and isolation}

The 50\% ethanol extraction of AC was found to show stronger inhibition effect on five human tumor cells than 95\% ethanol and water extraction [15]. And the extraction was processed as described previously. The fresh tubers of $A C$ (90 kg) were washed, sliced, dried in the sun and then extracted with $50 \%$ ethanol three times (1:8, 1:6 and 1:6, w:v), and the extract was evaporated in vacuo to yield a residue (400 g). The residue was suspended in water, and then partitioned with petroleum ether, EtOAc and $\mathrm{n}-\mathrm{BuOH}$ ordinally. The three fractions and residual of water fraction were evaporated in vacuo. The weights of the four fractions were $9 \mathrm{~g}$, $170 \mathrm{~g}, 65 \mathrm{~g}$ and $152 \mathrm{~g}$, respectively.

\section{Sample preparation}

For HPLC analysis, $50 \mathrm{mg}$ samples each were dissolved in $\mathrm{MeOH}$ with $1 \mathrm{mg} / \mathrm{mL}$. The solutions were then filtered through $0.2 \mu \mathrm{m}$ filters (Millipore Co., Bedford, MA, USA). For bioassays, $30 \mathrm{mg}$ samples each were dissolved with DMSO or $70 \%$ ethanol into $30 \mathrm{mg} / \mathrm{mL}$. And the solutions were diluted into $50 \mu \mathrm{g} / \mathrm{mL}$ of top dose, then with 2 fold of serial dilution. Solution stocks were stored at $-20^{\circ} \mathrm{C}$ before use.

\section{Cell culture}

The human cell lines, MGC-803 (gastric cancer cells), Hela (cervical cancer cells), Bel7402 (liver cancer cells), K-562 (myelogenous leukemia cells), MDA-MB-435 (breast cancer cells) were obtained from the Cell Resource Center, the Shanghai Institute of Life Sciences (Shanghai, China). All cells were cultured in DMEM (Hyclone) with 10\% fetal bovine serum (Life Technology) and $1 \%$ penicillin-streptomycin in an atmosphere of $5 \% \mathrm{CO}_{2}$ at $37^{\circ} \mathrm{C}$.

\section{HPLC analysis}

The HPLC analysis was carried out on an Agilent 1200 HPLC system (Agilent Techonologies, Santa Clara, CA, USA), combined with Prodigy ODS (2) column of $250 \times$ $4.6 \mathrm{~mm}$ i.d., $5 \mu$ (Phenomenex, Torrance,CA, USA), and guard column of $7.5 \times 3.2 \mathrm{~mm}$ i.d.. Gradient elution was applied, using $\mathrm{MeOH}$ (solvent $\mathrm{A}$ ) and water (solvent $\mathrm{B}$ ) as mobile phase components. The flow rate was $1.0 \mathrm{~mL} / \mathrm{min}$ at $25^{\circ} \mathrm{C}$ and injection volume was $20 \mu \mathrm{L}$. Gradient elution started with $5 \%$ solvent A and $95 \%$ solvent B. The elution was changed to $10 \% \mathrm{~A}$ and $90 \% \mathrm{~B}$ at $10 \mathrm{~min}$, then to $50 \%$ $\mathrm{A}$ and $50 \% \mathrm{~B}$ at $15 \mathrm{~min}$, and ended with $80 \% \mathrm{~A}$ and $20 \% \mathrm{~B}$ at $70 \mathrm{~min}$. The detection wavelength was set to $205 \mathrm{~nm}$ (range of $196-450 \mathrm{~nm}$ ). 


\section{Cell growth inhibition assay}

The in vitro antiproliferation efficacy of four fractions from EAC on the five cancer cell lines was investigated by MTT assay [18]. Briefly, cells were plated in 96-well plate (2000 cells/well). After plating overnight, cells were starved without serum for $24 \mathrm{~h}$ before treatment with $50 \mu \mathrm{g} / \mathrm{mL}$ of samples for $24 \mathrm{~h} .10 \mu \mathrm{L}$ of $0.5 \mathrm{mg} / \mathrm{mL}$ MTT was added to each well. Then read the absorbance at $492 \mathrm{~nm}$. Experiments were conducted in triplicates. With the procedure above, $\mathrm{IC}_{50}$ were tested by $48 \mathrm{~h}$ treatment with various concentration of EAC-B. Additionally, EAC-B $\mathrm{IC}_{50} \mathrm{~s}$ of $24 \mathrm{~h}, 48 \mathrm{~h}$ and $72 \mathrm{~h}$ treatment on MGC-803 were tested.

\section{In vivo antitumor efficacy of EAC-B on MGC-803 tumor bearing nude mice}

Animal welfare and experimental procedures were in accordance with institutional guidelines for the care and use of laboratory animals and the related ethical regulations of Shanghai University of Traditional Chinese Medicine. BALB/c nude mice were subcutaneously injected at the right armpit with MGC-803 cells $(2 \times$ $10^{6} / 0.2 \mathrm{~mL}$ ). All mice were sexually divided into five groups randomly: negative control (PBS), CTX control (cyclophosphamide) and three testing groups, with five mice per group. The mice in CTX control group were peritoneally injected CTX $(0.05 \mathrm{~g} / \mathrm{kg})$ once a day, and the mice in drug/PBS groups were infused EAC-B intragastrically. The body weight was measured every day. On the $21^{\text {st }}$, the mice were killed and tumors were isolated and weighed.

\section{Hematoxylin and eosin (HE) staining}

Ten \% formalin-fixed tumor samples were dehydrated, embedded in the paraffin and sectioned into $4 \mu \mathrm{M}$ slices. The slices were visualized with $\mathrm{HE}$ staining.

\section{Hoechst 33342 stain}

MGC-803 cells were plated in 96-well plate (2000 cells/well). After plating for $24 \mathrm{~h}$, cells were incubated with $50 \mu \mathrm{g} / \mathrm{mL}$ of EAC-B for duration of $0,2,8 \mathrm{~h}$, then washed with PBS for twice prior to Hoechst $33342(10 \mu \mathrm{g} / \mathrm{mL})$ addition, and then incubated in dark for $20 \mathrm{~min}$. The morphologic change was observed with the fluorescent microscope.

\section{Cell cycle analysis by flow cytometry}

MGC-803 cells were plated in 6-well plates $\left(1 \times 10^{5}\right.$ cells/ well). After $24 \mathrm{~h}$ plating and then $24 \mathrm{~h}$ serum starvation, cells were incubated with the EAC-B for $4 \mathrm{~h}$ with various doses, then harvested by trypsinization, fixed with cold $70 \%$ ethanol at $4^{\circ} \mathrm{C}$ for $30 \mathrm{~min}$ and washed with PBS twice. The cell pellet was incubated in a solution containing $50 \mu \mathrm{g} / \mathrm{mL}$ propidium iodide (PI), $0.2 \mathrm{mg} / \mathrm{mL}$ RNase, and $0.1 \%$ Triton $\mathrm{X}-100$ at room temperature in dark for $30 \mathrm{~min}$. The cells were analyzed by flow cytometer (BD, FACSCalibur).

\section{Cell apoptosis analysis by flow cytometry}

In brief, we treated MGC-803 cells with various doses of EAC-B for $4 \mathrm{~h}$. Then cells were harvested, washed and incubated with the solution of Annexin V-FITC for $20 \mathrm{~min}$ and then PI $(50 \mu \mathrm{g} / \mathrm{mL})$ for $10 \mathrm{~min}$. All staining operations must be carried out on ice and in dark. The cells were analyzed by flow cytometer.

\section{Reverse transcriptase polymerase chain reaction (RT-PCR)} MGC-803 cells were harvested after treated with $31 \mu \mathrm{g} / \mathrm{mL}$ of EAC-B for $4 \mathrm{~h}$. Total RNA was extracted using Trizol reagent (Gibco). Equal amount $(1 \mu \mathrm{g})$ of total RNA samples were reverse transcribed into cDNA using reverse transcription kit (Gibco) and amplified. The primer sequences are as follows [19]. Cyclin D1, forward: $5^{\prime}$-CGT CCA TGC GGA AGA TC-3', reverse: 5' -CAG AGG GCA ACG AAG GT-3' (406 bp); GAPDH, forward: 5'-CGG AGT CAA CGG ATT TGG TCG TAT-3', reverse: 5' -AGC CTT CTC CAT GGT GGT GAA GAC-3' (306 bp). PCR was performed as follows: denaturation at $94^{\circ} \mathrm{C}$ for $3 \mathrm{~min}, 40$ cycles of $94^{\circ} \mathrm{C}$ for $30 \mathrm{~s}, 57^{\circ} \mathrm{C}$ for $30 \mathrm{~s}$ and $72^{\circ} \mathrm{C}$ for $2 \mathrm{~min}$, followed by a final extension at $72^{\circ} \mathrm{C}$ for $10 \mathrm{~min}$. Expression of the genes was analyzed by gel imaging system.

\section{Western blot assay}

MGC-803 cells were treated with various concentration of EAC-B for $24 \mathrm{~h}$. Cell lysates were prepared in a buffer containing $0.2 \%(\mathrm{w} / \mathrm{v})$ SDS, $0.5 \%(\mathrm{v} / \mathrm{v})$ Triton X-100, 0.5\% (w/v) sodium deoxycholate, $1 \mathrm{mM}$ PMSF, and $1 \%$ protease inhibitor cocktail. The total protein content was measured by BAC protein assay. The equal amount of protein was electrophoresed on 10\% SDS-PAGE and transferred to PVDF membranes. The membranes were blocked, incubated overnight with primary antibodies at $4^{\circ} \mathrm{C}$, and subsequently incubated with secondary horseradish peroxidase-conjugated goat anti-rabbit or goat anti-mouse IgG (Abcam). The following antibodies were used: Akt and p-Akt from Cell Signaling, cyclinD1, ERK, p-ERK, Bcl-2, Bax, GAPDH and $\beta$-actin from Santa Cruz. The blots were visualized using ECL detection reagents (Pierce).

\section{Caspase $3 / 7$ activity assay}

MGC-803 cells were plated in 96-well plate (4000 cells/well). After $24 \mathrm{~h}$, cells were treated with 0 to $50 \mu \mathrm{g} / \mathrm{mL}$ of EAC-B or culture medium ( $1 \% \mathrm{DMSO})$ for $5 \mathrm{~h}$, then added the equal volume reagent of Caspase3/7 (Promega), followed with standing for $30 \mathrm{~min}$. The contents of Caspase3/7 were quantified and reflected apoptosis by luminescence with microplate reader.

\section{Statistical analysis}

Statistical software SPSS15.0 was used for statistical analysis. Data were expressed as mean \pm SD. Difference between independent groups was analysed using the Student's $t$-test. 


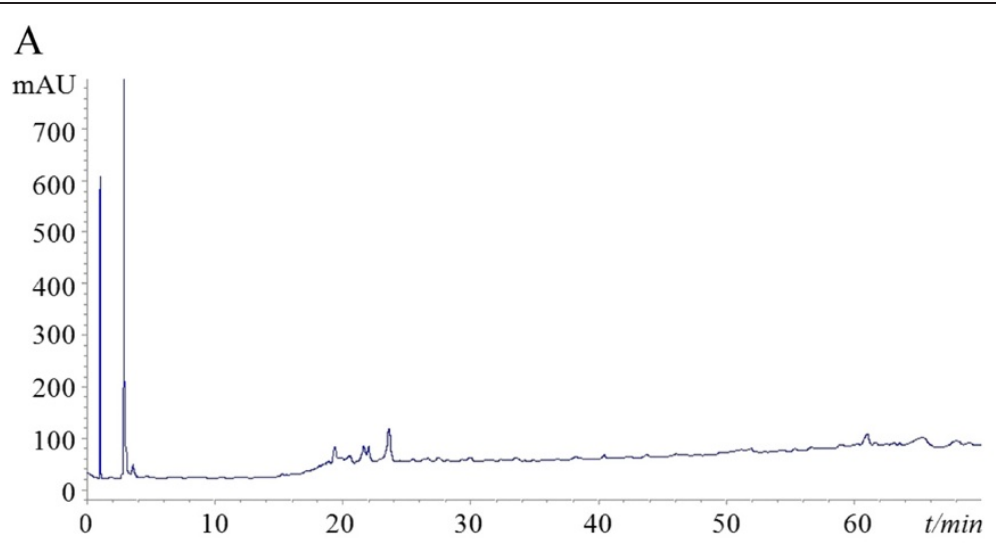

B

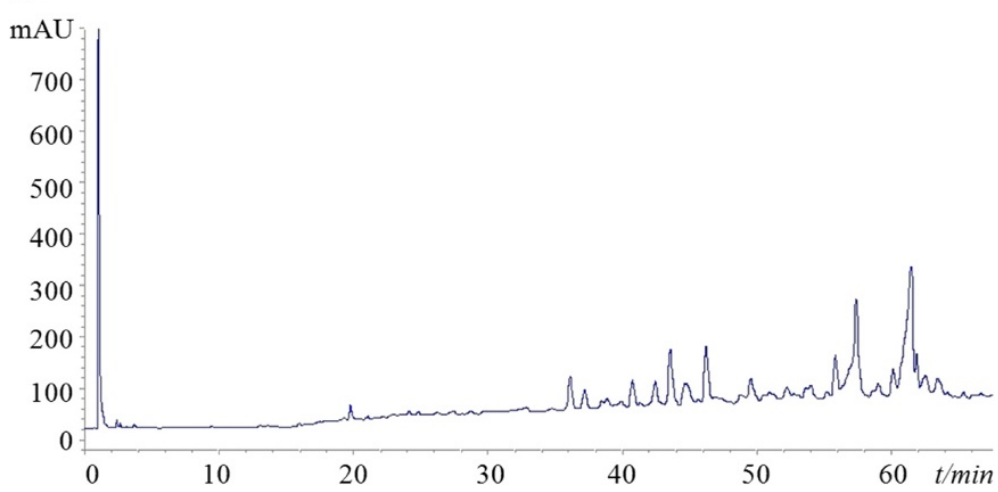

Figure 1 HPLC-UV profiles of fractions partitioned from the EAC. (A) EAC-B; (B) EAC-PE. (UV $\lambda=205 \mathrm{~nm})$.

\section{Results}

\section{HPLC profile}

To distinguish and deepen our previous study $[13,15]$, the HPLC chromatograms demonstrated the phytochemistry difference between EAC-B and EAC-PE. As shown in Figure 1, we detected five major peaks in EAC-B HPLC chromatograms, while eleven major peaks were confirmed in EAC-PE. The retention times were also different (EAC-B: 1.2, 2.5, 18.6, 21.9, $23.9 \mathrm{~min}$; EAC-PE: 1.5, 20.2, 36.1, 37.2, 41.3, 43.1, 46.2, 49.3, 56.2, 57.5, $61.8 \mathrm{~min})$. The HPLC chromatograms demonstrated the phytochemistry difference between EAC-B and EAC-PE.
Antiproliferation activity of EAC-B in human cell lines Four fractions of EAC were prepared and their growth inhibition activity at high concentration was identified using MTT assay against a panel of human cancer cell lines (Table 1). EAC-B showed more than 50\% antiproliferative activity against four cell lines at $50 \mu \mathrm{g} / \mathrm{mL}$ except Hela cell. The EAC-B presented the antiproliferation on four cancer cell lines dose-dependently with $48 \mathrm{~h}$ treatment. MGC-803 showed the highest susceptibility to the $\mathrm{EAC}-\mathrm{B}$ with the $\mathrm{IC}_{50}$ value of $24.1 \mu \mathrm{g} / \mathrm{mL}$. Furthermore, EAC-B showed inhibition effect on gastric carcinoma in time-dependent manner (Figure 2) with the most potent $\mathrm{IC}_{50}(18.8 \mu \mathrm{g} / \mathrm{mL})$ after $72 \mathrm{~h}$ treatment.

Table 1 Inhibition effect of different fraction of EAC on 5 cancer cell lines

\begin{tabular}{|c|c|c|c|c|c|}
\hline \multirow[t]{2}{*}{ Origin } & \multicolumn{4}{|c|}{ Single dose $(50 \mu \mathrm{g} / \mathrm{mL})$ inhibition at $24 \mathrm{~h}(\%)$} & \multirow{2}{*}{$\begin{array}{l}\mathrm{IC}_{50} \text { of EAC-B } \\
\text { at } 48 \mathrm{~h}(\mu \mathrm{g} / \mathrm{mL})\end{array}$} \\
\hline & EAC-PE & EAC-B & EAC-E* & $E A C-W^{* *}$ & \\
\hline Gastric carcinoma (MGC-803) & $21.3 \pm 1.3$ & $87.0 \pm 6.2$ & $16.0 \pm 2.0$ & $12.1 \pm 1.7$ & $24.1 \pm 3.7$ \\
\hline Breast carcinoma (MDA-MB-435) & $19.9 \pm 3.9$ & $76.0 \pm 0.4$ & $15.4 \pm 3.7$ & $10.2 \pm 3.0$ & $26.0 \pm 2.7$ \\
\hline Myelogenous leukemia carcinoma (K-562) & $30.3 \pm 0.3$ & $73.9 \pm 0.3$ & $22.5 \pm 3.8$ & $17.3 \pm 3.6$ & $27.9 \pm 7.8$ \\
\hline Liver carcinoma (Bel7402) & $18.3 \pm 1.1$ & $65.9 \pm 5.1$ & $15.8 \pm 3.6$ & $3.6 \pm 3.1$ & $39.9 \pm 6.1$ \\
\hline Cervical carcinoma (Hela) & $11.6 \pm 4.9$ & $19.3 \pm 1.3$ & $13.5 \pm 0.7$ & $2.6 \pm 1.5$ & $>50$ \\
\hline
\end{tabular}

*EAC-E: the EtOAc fraction of EAC; ${ }^{*}$ EAC-W: the water fraction of EAC. 


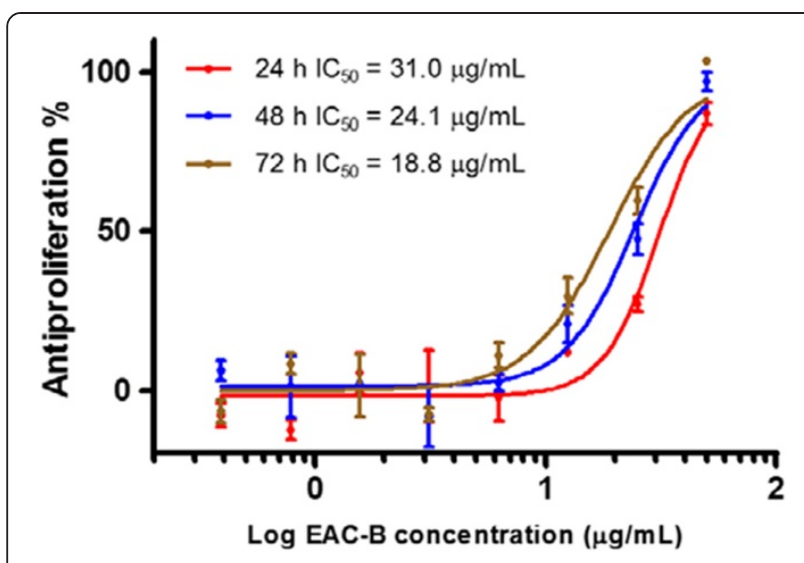

Figure 2 Cytotoxic effect of EAC-B on MGC-803 in time-dependent manner by MTT assay. MGC-803 was treated with various doses of EAC-B for 24,48 , or 72 h. $n=3$, mean \pm SD.

\section{Reduced tumor growth and increased necrosis in EAC-B} treated mice

EAC-B inhibited the tumor growth in a dose-dependent manner (Figure 3). $1 \mathrm{~g} / \mathrm{kg}$ and $5 \mathrm{~g} / \mathrm{kg}$ were effective dose with approximately 50-90\% of antitumor activity. Extract treatment had better role in female mice than in male mice, especially in high dose treatment $(1 \mathrm{~g} / \mathrm{kg}$ and $5 \mathrm{~g} / \mathrm{kg}$ ). Although $5 \mathrm{~g} / \mathrm{kg}$ was quite a high dose in our experiment, $5 \mathrm{~g} / \mathrm{kg}$ didn't present significant difference to $1 \mathrm{~g} / \mathrm{kg}$ to the antitumor effect. Furthermore, all mice, including of mice of $5 \mathrm{~g} / \mathrm{kg}$ groups, were alive until sacrifice, perhaps suggesting that the low toxicity of EAC-B. In treated mice, loss of quite amount of cells (arrows) indicated areas of necrosis by EAC-B.

Changes of cell cycle detected by flow cytometric analysis As shown in Figure 4A and B, the cell cycle of MGC-803 cells was changed obviously. Compared to the EAC-B free group, as early as $4 \mathrm{~h}$, the number of cells in the G0/G1 phase was significantly increased in a dose-dependent manner. Cell amount in the $\mathrm{S}$ and G2 phase did not present any trend. The progression of cell cycle was arrested at G0/G1 phase.

\section{Effects of EAC-B on the mRNA and protein expression of} cell cycle protein (Cyclin D1)

It was identified early on $4 \mathrm{~h}$ that EAC-B reduced the mRNA level of cyclin D1 $(p<0.001)$. Similarly, cyclin D1 protein level, detected by western blotting, was downregulated $(p<0.001)$ (Figure 5$)$.

\section{A}

MGC-803 Tumor Weights in Male Nude Mice

MGC-803 Tumor Weights in Female Nude Mice
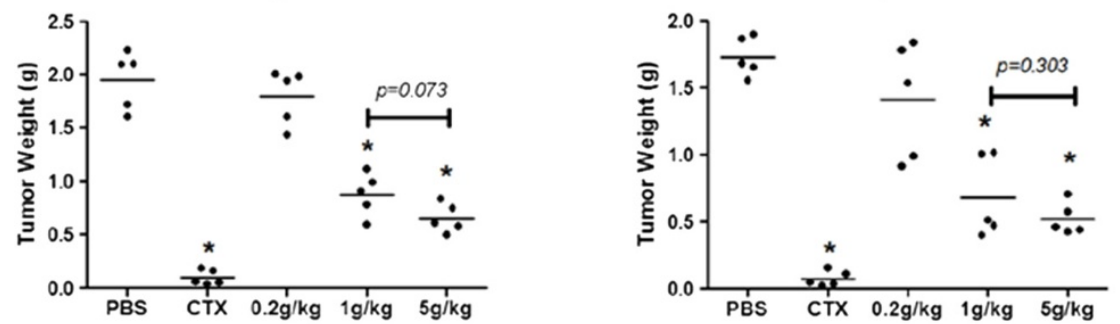

B

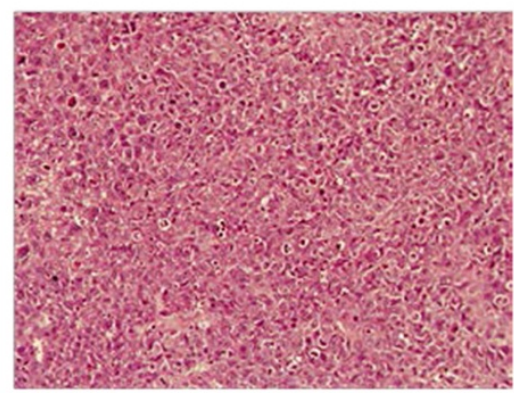

PBS

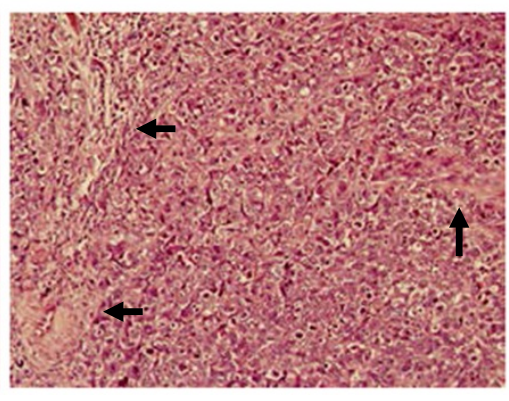

EAC-B

Figure 3 Inhibited effect of EAC-B to tumor growth in vivo. (A) BALB/C nude mice were sacrificed at the $21^{\text {st }}$ days after subcutaneous injection of MGC-803 cells $\left(2 \times 10^{6}\right.$ /mouse) followed by treatment. The treatment included of PBS (control), CTX (cyclophosphamide, peritoneal injection), EAC-B of $0.2,1$ and $5 \mathrm{~g} / \mathrm{kg}$ (intragastric infusion). The scatter diagrams represented the tumor weight of each female and male animal. Significant difference were labelled with asterisk $(p<0.05)$ compared to PBS groups. (B) Histological change of the tumor tissue by HE staining ( $\times 20$ of magnification). The loss of tumor cells (arrows) indicated necrosis (right). 


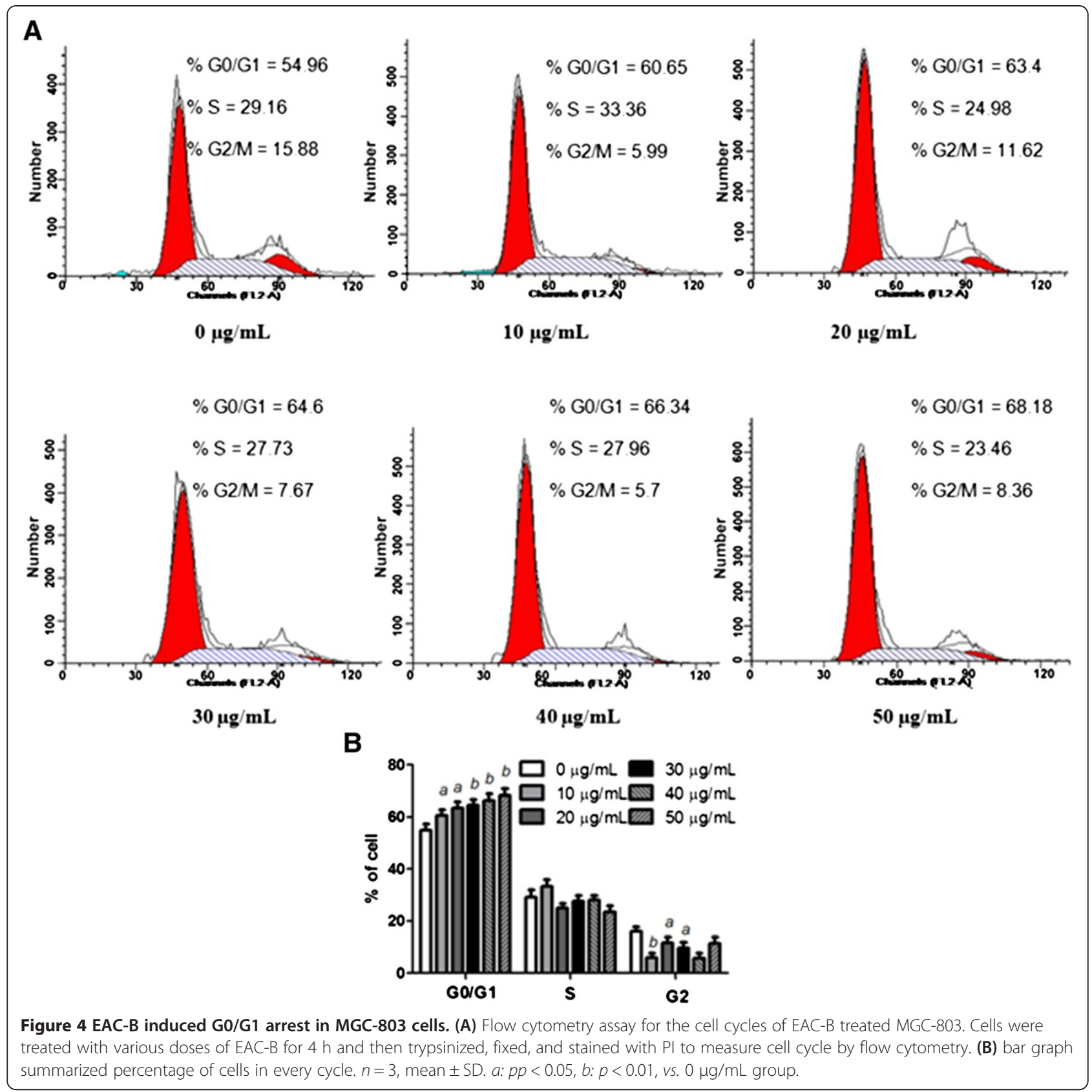

EAC-B induced apoptosis in MGC-803 cells

In a pilot assay of Hoechst 33342, a rapid assay based on fluorescent detection of compacted chromatin in apoptotic cells, MGC-803 cells were incubated with $50 \mu \mathrm{g} / \mathrm{mL}$ of EAC-B by $0,2,8 \mathrm{~h}$. After $2 \mathrm{~h}$ incubation, MGC-803 cells began to apoptosis. After $8 \mathrm{~h}$, some cells died (Figure 6).

\section{Flow cytometric analysis of cell apoptosis}

Flow cytometry was used to identify and quantify the apoptosis and necrosis cells. MGC-803 cells were treated with EAC-B of 0, 10, 20, 30, 40 and $50 \mu \mathrm{g} / \mathrm{mL}$. Then cells were stained with Annexin V-FITC/PI and subsequently analysed by flow cytometry. The four quadrants of the dual parameter fluorescent dot plots represented different states of the cells. The viable cells population was in the lower left quadrant (Annexin V-/PI-). The early apoptotic cells were in the lower right quadrant (Annexin V+/PI-) and the ones in late apoptosis were in the upper right quadrant (Annexin $\mathrm{V}+/ \mathrm{PI}+$ ). As shown in Figure $7 \mathrm{~A}$ and $\mathrm{B}$, as early as $4 \mathrm{~h}$, with the increasing concentration of the EAC-B, the proportion of apoptotic cells increased. 

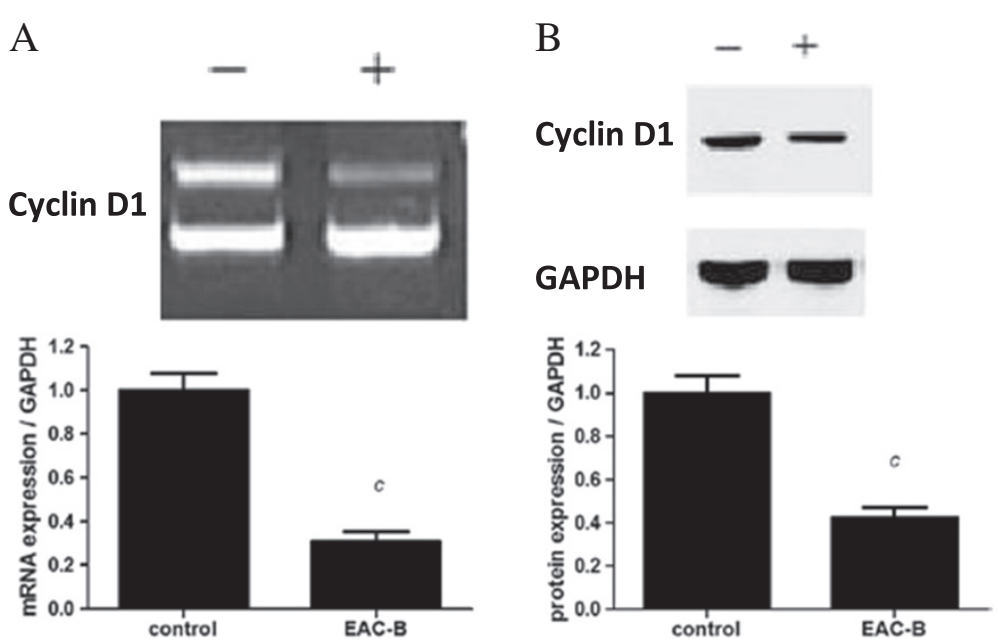

Figure 5 EAC-B downregulated cell cycle related gene/protein (Cyclin D1) expression. MGC-803 cells were treated with or without $31 \mu \mathrm{g} / \mathrm{mL}$ of EAC-B for $4 \mathrm{~h}$ prior to RT-PCR (A) and western blotting (B) analysis. GADPH was housekeeping control. Left: representative immunoblot; Right: densitomentric analysis. $n=3$, mean \pm SD. $c: p<0.001$, vs. control group.

Both of the Hoechst and flow cytometry results indicated that the EAC-B may induce apoptosis in MGC803 cells.

\section{EAC-B inhibited Akt and ERK in MGC-803 cells}

The biochemical mechanism by which EAC-B caused cells to enter apoptosis was explored with the PI-3 K and MAPK signaling pathway. The expression of $\mathrm{p}$-Akt, Akt, p-ERK and ERK after drug treatment were measured by western blotting (Figure $8 \mathrm{~A}$ and $\mathrm{B}$ ). EAC-B reduced both expression of $\mathrm{p}$-Akt and p-ERK by dosedependent manner, but no effect on Akt and ERK. This means EAC-B may affect the PI-3 K and MAPK pathway in cell apoptosis.

\section{EAC-B increased $\mathrm{Bax} / \mathrm{Bcl}-2$ ratio in MGC-803 cells}

To further investigate the effect of EAC-B on apoptosisregulatory proteins, we also examined the expression of anti-apoptosis molecule Bcl-2 and pro-apoptosis molecule Bax in MGC-803 cells. As shown in Figure 8C and D, EAC-B significantly decreased the expression of Bcl-2 and increased the expression of Bax in a dose-dependent manner, which caused an increased ratio of Bax to Bcl-2 (Figure 8E).

\section{EAC-B extract activated Caspase $3 / 7$}

Since one possible apoptotic pathway has been thought that cytochrome $\mathrm{C}$ released from mitochondria could trigger the caspase cascade [19], we evaluated the Caspase3/7 activity in MGC-803 cells with treatment of EAC-B. As shown in Figure 9. Caspase3/7 activity, measured by using a luminescent caspase activity assay kit, increased proportionately with EAC-B concentration of treatment in MGC-803 cells.

\section{Discussion}

AC has been applied for treating cancer patients in traditional Chinese medicine. The antitumor effect of EAC was reported in our previous study [15], and 50\% ethanol extract showed the strongest inhibition to cancer cell lines. In this paper, we further partitioned the $50 \%$ ethanol extract and investigated the antitumor effect and mechanism of EAC for the first time. The four extractive fractions were screened in terms of antiproliferation in vitro against various cancer cell lines. EAC-B showed
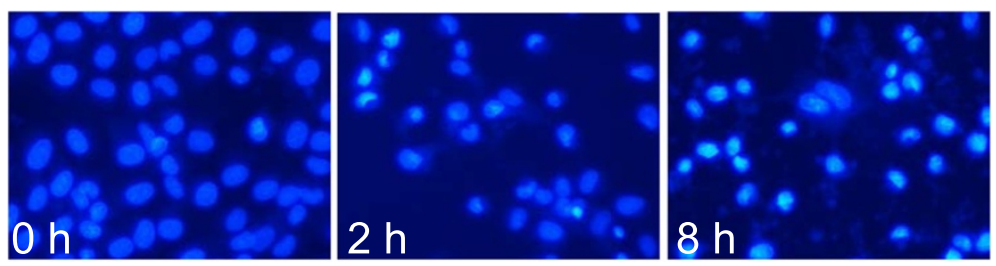

Figure 6 Hoechst 33342 staining exhibited that EAC-B induced chromatin shrinking of MGC-803 cells. Representative pictures of 3 independent experiments are shown. 


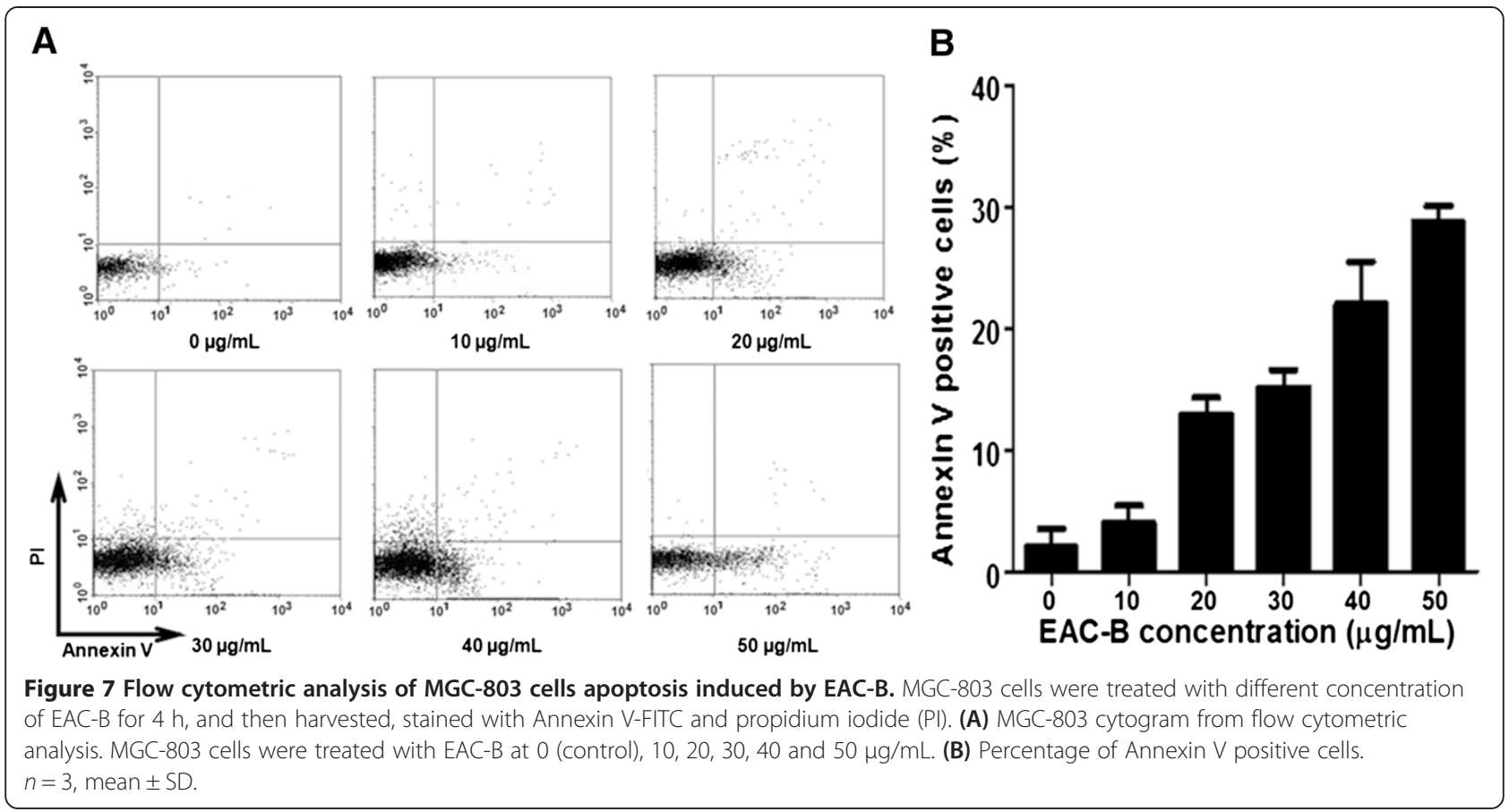

the most potent antiproliferative effect on the gastric cancer cell line of MGC-803 with $\mathrm{IC}_{50}$ value of $18.8 \mu \mathrm{g} /$ $\mathrm{mL}$, while traditionally, $\mathrm{AC}$ was used in folk medicine for GC. To distinguish the component difference between EAC-B and EAC-PE [13], we demonstrated the phytochemistry by HPLC. Herein, EAC-B was scrutinized the potential and mechanism against $\mathrm{GC}$ in vitro and in vivo.

In vivo, EAC-B exerted stronger tumor inhibition on female mice than male mice, especially with high dose treatment. The gender susceptibility on GC is in accordance with the AC clinical application on breast cancer. Furthermore, compared with the highest dose $(0.8 \mathrm{~g} / \mathrm{kg})$ in Fang's report [16], we treated the model mice with higher dose treatment up to $5 \mathrm{~g} / \mathrm{kg}$. It was interesting that the mice were all alive when sacrifice, which was speculated the low toxicity of EAC-B in animal models.

Depending on the disabled cell cycle regulation, uncontrolled cell proliferation is the hallmark of cancer [20]. In cell culture, cell cycle arrest sufficient to cell senescence is a common barrier to cancer [21]. Cyclins are well-studied cell cycle regulators. Cyclin D1 is particularly required at $\mathrm{G} 1$ to $\mathrm{S}$ phase. Cyclin D1, together with its cell dependent kinase 4/6 partner, is responsible for the transition to $\mathrm{S}$ phase by retinoblastoma protein (Rb) phosphorylation [22]. Over-expression of Cyclin D1 oncogene can release cell from their normal cell cycle control and causes transformation to neoplasia [22]. Novel antitumor agent may derive from Cyclin D1 inhibition [23]. In our study, EAC-B inhibited the cell proliferation via G0/G1 cell cycle arrest, accompanied with a decrease of Cyclin D1 both on protein and mRNA level. Therefore, our results suggested that EAC-B suppressed MGC-803 proliferation by affecting cell cycle arrest and inhibiting Cyclin D1.

In this study, nucleus shrinking, one of morphologic alterations of apoptosis [24] was detected by Hoechst staining. Apoptotic cells ratio was increased in a dosedependent manner by EAC-B by flow cytometry. These suggested that the mechanism of tumor inhibition by EAC-B was associated with cell apoptosis. MTT is an index of mitochondrial viability because it is reduced by metabolically active mitochondria [25]. Our results indicated that EAC-B exerted a decrease in MGC-803 cells mitochondrial viability with $\mathrm{IC}_{50}$ value of $18.8 \mu \mathrm{g} / \mathrm{mL}$. The result suggested that the apoptosis pathway may be controlled by mitochondrion. The PI-3 K/Akt pathway is a significant anti-apoptotic/survival signaling pathway in cancer cells. Its role in the regulation of mitochondrial functions has drawn more attentions [26]. Akt, a protooncogene, is a key protein in this pathway. The phosphorylation of Akt leads to its activation [24]. Bcl-2 and Bax, the anti-apoptosis protein and pro-apoptosis protein, act as the downstream regulators of Akt and activated Akt, following with regulating mitochondrial outer membrane permeabilization that favors the release different apoptogenic factors, such as cytochrome C $[27,28]$, and hence to trigger apoptotic caspase activation, including caspase 3/7. Activated Akt phosphorylates BAD, dissociates BAD from Bcl-2 or Bcl-xL and thus suppresses apoptosis [29]. Phosphorylation of Bax by Akt or activated Akt disables its translocation to the mitochondrial 


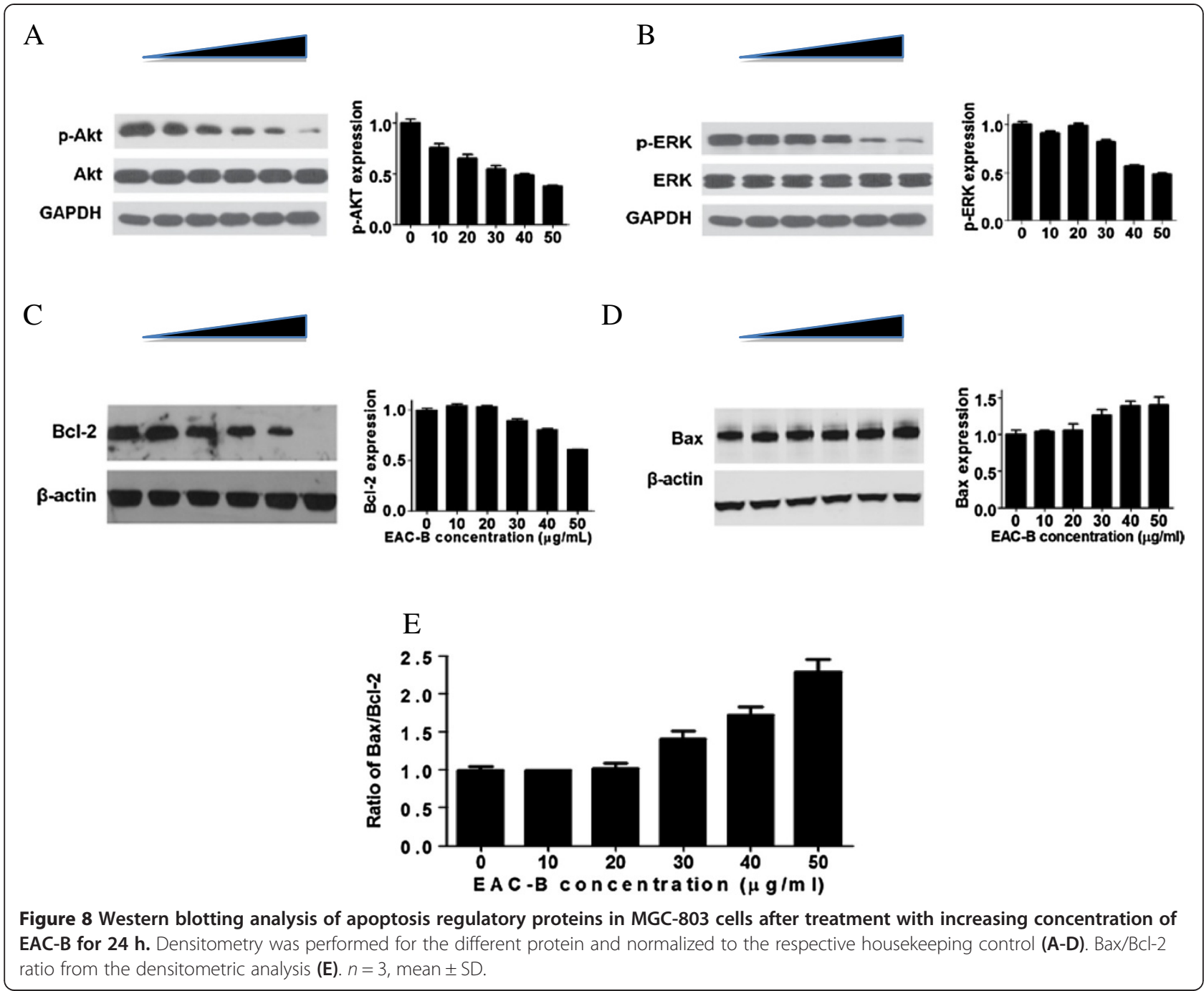

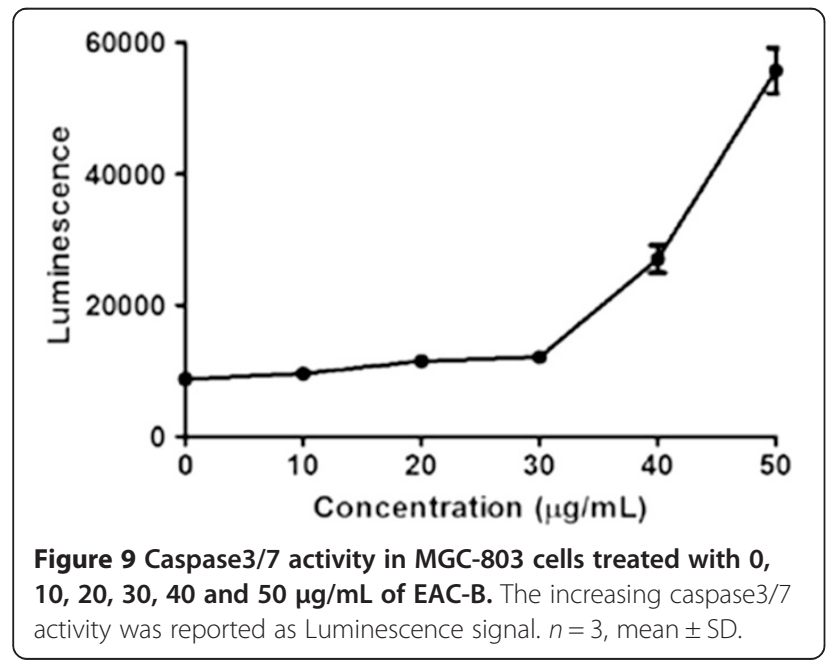

membrane and hence decreases permeabilization. The ratio of Bax/Bcl-2 determines the susceptibility of MGC-803 to apoptosis [30,31]. In this study, p-AKT was significantly decreased by EAC-B in a dose-dependent manner, while EAC-B treatment didn't change AKT expression. We also found that the expression of $\mathrm{Bcl}-2$ protein decreased and the expression of Bax protein increased which led to an increase of the $\mathrm{Bax} / \mathrm{Bcl}-2$ ratio. The present results showed that EAC-B exhibited antitumor by stimulating apoptosis.

A growing number of studies have confirmed the implantation of the Ras/Raf/ERK signaling pathway in the induction of cell apoptosis in vitro and in vivo [32]. ERK activity could also promote cytochrome $\mathrm{C}$ release by modulating $\mathrm{Bcl}-2$ family protein expression. Furthermore, MEK/ERK activity has been associated with the upregulation of pro-apoptotic members of the $\mathrm{Bcl}-2$ family, and the downregulation of anti-apoptotic members, such as Bcl-2 and Bcl-xL. 
EAC-B treated MGC-803 cells may induce the apoptosis by inhibition of p-Akt and p-ERK, following with involvement of $\mathrm{Bcl}-2$, Bax, and cytochrome $\mathrm{C}$ release and apoptosis execution by caspase $3 / 7$.

\section{Conclusions}

In summary, our results showed that EAC-B significantly inhibited cancer cells growth in vitro and in vivo. The molecular mechanisms may involve 1) PI-3 K/Akt pathway of apoptosis; 2) ERK activity of apoptosis; 3) triggering of mitochondrial pathway; 4) connection by $\mathrm{Bcl}-2$ and $\mathrm{Bax}$; 5) G0/ G1 cell cycle arrest. It is clinically confirmed that Alocasia is effective for cancer treatment proved by modern Chinese medicine and folk medicine, especially for GC and breast cancer. The research of Alocasia is not systematic despite efforts people devote to. Our study for $\mathrm{BuOH}$ fraction of extract from A. cucullata (one species of Alocasia), may discover that EAC-B might be used as a potential agent for treating GC.

\section{Ethics statements}

All the procedures were in strict accordance with the PR China legislation on the use and care of laboratory animals and with the guidelines established by Institute for Experimental Animals of Shanghai University of TCM and were approved by the university ethical committee for animal experiments.

\section{Abbreviations \\ AC: Alocasia cucullata (Lour.) G. Don (Chinese taro); EAC: The extract of Alocasia cucullata (Lour.) G. Don; EAC-B: n-BuOH fraction of EAC; GC: Gastric cancer; HE: Hematoxylin and eosin; PI: Propidium iodide; EAC-PE: Petroleum ether fraction of EAC.}

\section{Competing interests}

The authors declare that they have no competing interests.

\section{Authors' contributions}

XWZ formulated the original ideas and working hypothesis; WP and ZYC designed the research studies; WP, ZYC and XT carried out the experiments; $X T, Z Y C$ and WP analyzed and interpreted the data; WP and ZYC wrote the first draft of the manuscript; XWZ revised and wrote the final draft of the manuscript. All authors read and approved the final manuscript.

\section{Acknowledgements}

This study was supported by grant (A1-20140371) from Project of Shanghai Education Commission within budget.

\section{Author details \\ 'Department of Medical Oncology, Fudan University Shanghai Cancer Center, Fudan University, Shanghai, China. ${ }^{2}$ Department of Oncology, Shanghai Medical College, Fudan University, Shanghai, China. ${ }^{3}$ Department of Pathology, Sichuan College of Traditional Chinese Medicine, Mianyang, China. ${ }^{4}$ Shanghai University of Traditional Chinese Medicine Engineering Research Center of Modern Preparation Technology of TCM, Ministry of Education, Room1107, No. 1200 Cai Lun Road, Pudong District, Shanghai, China.}

Received: 19 August 2014 Accepted: 13 February 2015

Published online: 26 February 2015

\section{References}

1. Wang S, Penchala S, Prabhu S, Wang J, Huang Y. Molecular basis of traditional Chinese medicine in cancer chemoprevention. Curr Drug Discovery Technol. 2010;7:67-75.

2. American Cancer Society. Global Cancer Facts \& Figures 2nd Edition. Atlanta: American Cancer Society; 2011.

3. Gastric Group, Paoletti X, Oba K, Burzykowski T, Michiels S, Ohashi Y, et al. Benefit of adjuvant chemotherapy for resectable gastric cancer: a meta-analysis. JAMA. 2010;303:1729-37.

4. Verpoorte R. Pharmacognosy in the new millennium: leadfinding and biotechnology. J Pharm Pharmacol. 2000;52:253-62.

5. Molassiotis A, Potrataa B, Cheng KK. A systematic review of the effectiveness of Chines herbal medication in symptom management and improvement of quality of life in adult cancer patients. Complement Ther Med. 2009;17:92-120.

6. Liu J, Li X, Liu J, Ma L, Li X, Fønnebø V. Traditional Chinese medicine in cancer care: a review of case reports published in Chinese literature. Forsch Komplementmed. 2011:18:257-63.

7. Gan T, Wu Z, Tian L, Wang Y. Chinese herbal medicines for induction of remission in advanced or late gastric cancer. Cochrane Database Syst Rev. 2010;20:8-18.

8. Khanha TD, Hongb NH, Xuanc TD, Chung M. Paddy weed control by medicinal and leguminous plants from Southeast Asia. Crop Prot. 2005:24:421-31.

9. Ke Y, Zhou XJ, Bai QM, He B. Investigation on Resources and Use of Alocasia cucullata G Don in China. J Hubei Agri Col. 1999;19:11-3.

10. Zhang HW, Guo W, Mo ZX. Identification of Characters of Leaf Venation of Alocasia cucullata and Alocasia macrorrhiza. Chin J Exper Tradi Med Form. 2012:8:129-32

11. Yang $X$, Guan PC. Purifigation and characterization of alectin from Alocasia cucullata. J South Chin Agri Univ. 1998;19:106-11.

12. Han HC, Chen PF. Research progress of the anti-cancer effect of the varieties of Chinese medicine "Seliugu". Yunnan J Tradi Chin Med Mater Med. 2007:7:51-3.

13. Lei $X, X u Z Z$, Wang $Y$, Feng $Y$, Zheng XW. Advances in chemical constituents and biological activity of Alocasia. Chin J New Drugs A. 2013;3:2-5.

14. Kaur A, Kamboj SS, Singh J, Saxena AK, Dhuna V. Isolation of a novel $\mathrm{N}$-acetyl-D-lactosamine specific lectin from Alocasia cucullata (Schott.). Biotechnol Lett. 2005;27:1815-20.

15. Lei $X$, Feng $Y$, Liang S, Wang $Y$, Zheng XW. Antitumor Effect and Chemical Study of the Petroleum ether Fraction from the Rhizome of Alocasia cucullatta (Lour). Schott. Chin J Pharm. 2012;43:340-3.

16. Peng Q, Cai H, Sun X, Li X, Mo Z, Shi J. Alocasia cucullata Exhibits Strong Antitumor Effect In Vivo by Activating Antitumor Immunity. PLoS One. 2013;8(9):e75328

17. Fang S, Lin C, Zhang Q, Wang L, Lin P, Zhang J, et al. Anticancer potential of aqueous extract of Alocasia macrorrhiza against hepatic cancer in vitro and in vivo. J Ethnopharmacol. 2012;141:947-56.

18. Mosmann T. Rapid colorimetric assay for cellular growth and survival: application to proliferation and cytotoxicity assays. J Immunol Methods. 1983;16(1-2):55-63.65.

19. Li GQ, Xie J, Lei XY, Zhang L. Macrophage migration inhibitory factor regulates proliferation of gastric cancer cells via the PI3K/Akt pathway. World J Gastroenterol. 2009;15:5541-8.

20. Sherr CJ. Cancer cell cycles. Science. 1996;274:1672-7.

21. Mikhail VB. Cell cycle arrest is not senescence. Aging (Albany NY). 2011:3(2):94-101.

22. Donnellan R, Chetty R. Cyclin D1 and human neoplasia. Mol Pathol. 1998;51:1-7.

23. Soria GJ, Orea SM. Apoptosis. Rev Alerg Mex. 2002:49:121-8.

24. Alessi DR, Andjelkovic M, Caudwell B, Cron P, Morrice N, Cohen P. Hemmings B. A., Mechanism of activation of protein kinase B by insulin and IGF-1. EMBO J. 1996:15:6541-51.

25. Galambos B, Csönge L, Olah A, Versen R, Tamas L, Zsoldos P. Quantitative reduction of methyl tetrazolium by fresh vein homograft biopsies in vitro is an index of viability. Eur Surg Res. 2004;36:371-5

26. Stiles BL. PI-3-K and AKT: Onto the mitochondria. Adv Drug Deliv Rev. 2009;61:1276-82.

27. Low IC, Kang J, Pervaiz S. BCl-2: a prime regulator of mitochondrial redox metabolism in cancer cells. Antioxid Redox Signal. 2011;15:2975-87.

28. Renault TT, Manon S. Bax: Addressed to kill. Biochimie. 2011:93:1379-91.

29. Zha J, Harada H, Yang E, Jockel J, Korsmeyer SJ. Serine phosphorylation of death agonist $B A D$ in response to survival factor results in binding to 14-3-3 not BCL-X(L). Cell. 1996;87(4):619-28. 
30. Jiang CG, Liu FR, Yu M, Li JB, Xu HM. Cimetidine induces apoptosis in gastric cancer cells in vitro and inhibits tumor growth in vivo. Oncol Rep. 2010;23:693-700.

31. Su XL, Ouyang XH, Xu GH, Shen J, Wang ZY. Effect of ACBP-S on cell cycle and apoptosis in human gastric cancer cells. Chin J Chin Mater Med. 2008;30:422-7.

32. Cagnol S, Chambard JC. ERK and cell death: mechanisms of ERK-induced cell death-apoptosis, autophagy and senescence. Febs J. 2010;277:2-21.

Submit your next manuscript to BioMed Central and take full advantage of:

- Convenient online submission

- Thorough peer review

- No space constraints or color figure charges

- Immediate publication on acceptance

- Inclusion in PubMed, CAS, Scopus and Google Scholar

- Research which is freely available for redistribution 